\title{
Modified task-based learning program promotes problem-solving capacity among Chinese medical postgraduates: a mixed quantitative survey
}

Yanping Tian ${ }^{\dagger}$, Chengren Li ${ }^{\dagger}$, Jiali Wang ${ }^{\dagger}$, Qiyan Cai, Hanzhi Wang, Xingshu Chen, Yunlai Liu, Feng Mei, Lan Xiao, Rui Jian ${ }^{*}$ and Hongli Li

\begin{abstract}
Background: Despite great advances, China's postgraduate education faces many problems, for example traditional lecture-based learning (LBL) method provides fewer oppotunities to apply knowledge in a working situation. Task-based learning (TBL) is an efficient strategy for increasing the connections among skills, knowledge and competences. This study aimed to evaluate the effect of a modified TBL model on problem-solving abilities among postgraduate medical students in China.

Methods: We allocated 228 first-year postgraduate students at Third Military Medical University into two groups: the TBL group and LBL group. The TBL group was taught using a TBL program for immunohistochemistry. The curriculum consisted of five phases: task design, self-learning, experimental operations, discussion and summary. The LBL group was taught using traditional LBL. After the course, learning performance was assessed using theoretical and practical tests. The students' preferences and satisfaction of TBL and LBL were also evaluated using questionnaires.

Results: There were notable differences in the mean score rates in the practical test $(P<0.05)$ : the number of high scores $(>80)$ in the TBL group was higher than that in the LBL group. We observed no substantial differences in the theoretical test between the two groups $(P>0.05)$. The questionnaire results indicated that the TBL students were satisfied with teaching content, teaching methods and experiment content. The TBL program was also beneficial for the postgraduates in completing their research projects. Furthermore, the TBL students reported positive effects in terms of innovative thinking, collaboration, and communication.

Conclusions: TBL is a powerful educational strategy for postgraduate education in China. Our modified TBL imparted basic knowledge to the students and also engaged them more effectively in applying knowledge to solve real-world issues. In conclusion, our TBL established a good foundation for the students' future in both medical research and clinical work.
\end{abstract}

Keywords: Modified task-based learning program, Medical postgraduate education, Problem-solving capacity, Immunohistochemistry

\footnotetext{
*Correspondence: 370107455@qq.com; lihongli@tmmu.edu.cn

${ }^{\dagger}$ Equal contributors

Department of Histology and Embryology, Third Military Medical University,

30\# Gaotanyan St., Shapingba District, Chongqing 400038, China
} 


\section{Background}

Medical education is a continuous, lifelong process and postgraduate medical education (PGME) is an important part of that process. PGME is a key element in the training of medical professionals and developing their innovative ability [1]. In China, postgraduate education started in 1949. As of 2014, it had produced 2 million enrolled graduate students with about 70,000 doctoral degree recipients and 500,000 master's degree recipients each year [2]. With this large number of postgraduate students, China's postgraduate educational system faces many problems $[2,3]$. Policy reforms with respect to faculty development, quality standardization, curriculum reform and accreditation are currently being implemented to adapt the challenges of rapidly changing, globalized education $[4,5]$.

At Third Military Medical University, PGME is a 3-year program. The 1st year is devoted to basic knowledge. The subsequent 2 years focus on research or clinical work and students who wish to obtain a master's degree must publish an article in an academic journal $[6,7]$. In our university, postgraduate courses consist of core and elective curricula. Immunohistochemistry is an elective curriculum in early PGME and widely applied in medical research and clinical diagnosis [8]. Many postgraduates use immunohistochemical techniques to complete their research as part of their postgraduate degree work. In China, many university tutors teach immunohistochemistry using traditional lecturebased learning (LBL). LBL is a good method for imparting basic knowledge to students. Taught that way, many students acquire knowledge about immunohistochemistry but lack the ability to solve real associated problems. It often leads to unsatisfactory learning outcomes: students passively receive knowledge from instructors without having the motivation to study and innovate $[9,10]$. Developing key skills and innovation, such as problem-solving skills, is an important object in PGME $[11,12]$.

To meet these challenges, reforms in educational strategies have been recommended in the curricula of Chinese medical schools over the past 2 decades. One such strategy is that of a task-based learning (TBL) approach, in which learning takes place with respect to many tasks assigned by instructors $[13,14]$. TBL is similar to problem-based learning (PBL), but there are essential differences in strategy. In contrast to PBL, TBL focuses on a set of tasks; it offers practical advantages, saves resources, and increases the connections among skills, knowledge, and competences [15]. TBL has been shown to be an effective, efficient strategy in education [15]. In undergraduate education for health professionals, TBL supports the integration of medical knowledge with patient care by providing a context for learning and developing transferable skills [16].

The aim of the present study was to describe and evaluate TBL in teaching immunohistochemistry to postgraduates in China. Information gained from this study can help us understand our modified TBL in imparting basic knowledge to students and engage them more effectively in applying knowledge to solve real-world issues. It can also help them develop skills in collaboration and communication, thereby establishing a good foundation for basic medicine and clinical medical research work in the future.

\section{Methods}

\section{Participant sampling}

The participating students were 228 first-year postgraduates at Third Military Medical University (Chongqing, China); they were randomly allocated into two groups of 114: the TBL group and LBL group. Table 1 shows the basic characteristics of the two groups. No significant differences were evident between the two groups in terms of student numbers, sex, or age $(P>0.05)$.

\section{Teaching methods \\ TBL group}

The descriptive data of the TBL group appear in Table 1. This group of 114 students was randomly divided into 30 smaller groups, each composed of three to four participants. The TBL model consisted of five phases. Figure 1 presents the conceptual framework of that model.

Phase 1: Task design The tasks consisted of two parts. In the first part, a list of tasks covering all chapters of an immunohistochemistry textbook was prepared. The list was systematically clustered into three main groups: experimental methods, experimental tools and quantification of morphometric analysis. Further details of the tasks (for example, hematoxylin and eosin staining) appear in Table 2. In the second part, the task was the students' research project for their degree; it involved a typical medical case that demanded the use of immunohistochemical techniques (Table 3). A study guide explained the learning issues involved with each task.

Phase 2: Self-learning According to the questions and tasks from Phase 1, the team members made learning

Table 1 Basic characteristics of participants

\begin{tabular}{lll}
\hline Groups & $\begin{array}{l}\text { TBL group }(n=114) \\
\text { Number(\%) }\end{array}$ & $\begin{array}{l}\text { LBL group }(n=114) \\
\text { Number(\%) }\end{array}$ \\
\hline Male & $83(72.8)$ & $84(73.7)$ \\
Female & $31(27.2)$ & $30(26.3)$ \\
Specialty & \\
$\quad$ Clinical, academic & 81 & 82 \\
$\quad$ Research, academic & 33 & 32 \\
Mean (SD) & & $24.2(1.7)$ \\
Mean age (years) & $24.3(1.5)$ & \\
\hline
\end{tabular}




\begin{tabular}{|c|c|c|c|c|}
\hline $\begin{array}{l}\text { Phase } 1 \\
\text { Task design }\end{array}$ & $\begin{array}{l}\text { Phase } 2 \\
\text { Self-learning }\end{array}$ & $\begin{array}{l}\text { Phase } 3 \\
\text { Experimental } \\
\text { operation }\end{array}$ & $\begin{array}{l}\text { Phase } 4 \\
\text { Discussion }\end{array}$ & $\begin{array}{l}\text { Phase } 5 \\
\text { Summary }\end{array}$ \\
\hline $\begin{array}{l}\text { The list of } \\
\text { tasks involving } \\
\text { all chapters of } \\
\text { immunohist- } \\
\text { ochemistry and } \\
\text { postgraduates' } \\
\text { research } \\
\text { projects for } \\
\text { their degree } \\
\text { were prepared. }\end{array}$ & $\begin{array}{l}\text { According to } \\
\text { the questions } \\
\text { and tasks from } \\
\text { Phase } 1 \text {, team } \\
\text { members learn } \\
\text { relevant } \\
\text { information } \\
\text { and design } \\
\text { experiments. }\end{array}$ & $\begin{array}{l}\text { Based on the } \\
\text { tasks and } \\
\text { research plans } \\
\text { developed in } \\
\text { Phase 2, the } \\
\text { students } \\
\text { conducted } \\
\text { experiments } \\
\text { using } \\
\text { immunohistoc- } \\
\text { hemical method }\end{array}$ & $\begin{array}{l}\text { The team } \\
\text { delegates } \\
\text { presented } \\
\text { the team's } \\
\text { results and } \\
\text { held } \\
\text { discussions } \\
\text { with the } \\
\text { other groups. }\end{array}$ & $\begin{array}{l}\text { Teachers } \\
\text { summary basic } \\
\text { knowledge, basic } \\
\text { principle and } \\
\text { basic technical } \\
\text { skills and solve } \\
\text { the common } \\
\text { problems. } \\
\text { Students provide } \\
\text { suggestions on } \\
\text { the TBL teaching } \\
\text { mode. }\end{array}$ \\
\hline
\end{tabular}

Table 2 Tasks in the TBL model for immunohistochemistry and the task of hematoxylin and eosin staining as an example

\begin{tabular}{|c|c|}
\hline Principle tasks & Learning objectives \\
\hline \multirow[t]{8}{*}{ Experimental methods } & Paraffin section technique; Frozen section technique \\
\hline & HE staining; Silver staining \\
\hline & Nissl staining; Giemsa staining \\
\hline & Oil red O dyeing; Hoechst staining \\
\hline & Tissue microarrays; In situ hybridization \\
\hline & Periodic acid-Schiff (PAS) reaction \\
\hline & Immunoperoxidase immunohistochemistry \\
\hline & Immunofluorescence histochemistry \\
\hline \multirow[t]{4}{*}{ Experimental tools } & Confocal microscopy; Flow cytometer \\
\hline & Scanning electron microscope (SEM) \\
\hline & Transmission electron microscopy (TEM) \\
\hline & Immunoelectron microscopy \\
\hline \multirow[t]{2}{*}{ Quantification of morphometric analysis } & Quantification of morphological images \\
\hline & Stereology \\
\hline \multicolumn{2}{|l|}{ Questions } \\
\hline \multicolumn{2}{|c|}{ 1. What is your research project? Do you use hematoxylin-eosin staining (HE staining) in your research work? (Phase 1) } \\
\hline \multicolumn{2}{|c|}{ 2. What is the principle of HE staining? (Phase 1) } \\
\hline \multicolumn{2}{|c|}{ 3. What problems HE staining can solve? (Phase 1) } \\
\hline \multicolumn{2}{|c|}{ 4. What reagents are needed in this experiment? How to configure these buffer solutions? (Phase 3) } \\
\hline \multicolumn{2}{|c|}{ 5. What is the experimental protocol of HE staining? (Phase 3) } \\
\hline \multicolumn{2}{|c|}{ 6. How observed the experimental results of HE staining? (Phase 3) } \\
\hline \multicolumn{2}{|c|}{ 7. There are some key options and considerations to take into account.(Teachers provided, Phase 4) } \\
\hline \multicolumn{2}{|c|}{ 8. What are the advantages and disadvantages of HE staining compared with other methods? (Teachers provided, Phase 5) } \\
\hline
\end{tabular}


Table 3 Case materials and guiding questions

\begin{tabular}{|c|c|}
\hline Case & Questions \\
\hline \multirow{5}{*}{$\begin{array}{l}\text { Embryonic stem cells (ES cells) are pluripotent stem cells derived from the } \\
\text { inner cell mass of blastocyst. ES cells are able to differentiate to generate } \\
\text { primitive ectoderm, which ultimately differentiates into all derivatives of the } \\
\text { three primary germ layers: ectoderm, endoderm, and mesoderm, which } \\
\text { differentiate more than } 220 \text { cell types in the adult body. Because of their } \\
\text { plasticity and potentially unlimited capacity for self-renewal, ES cell therapies } \\
\text { have been proposed for regenerative medicine and tissue replacement after } \\
\text { injury or disease. They are also models for drug screening, gene research } \\
\text { and so on. }\end{array}$} & $\begin{array}{l}\text { 1. How to observe the development structures of three germ layers? } \\
\text { (HE staining) }\end{array}$ \\
\hline & $\begin{array}{l}\text { 2. How many neuroectoderm cells were obtained in ES cell } \\
\text { differentiation? (flow cytometry) }\end{array}$ \\
\hline & $\begin{array}{l}\text { 3. How to observe characteristic protein expression of } \\
\text { neuroectoderm? (Immunoperoxidase immunohistochemistry, } \\
\text { Immunofluorescence histochemistry, In situ hybridization) }\end{array}$ \\
\hline & $\begin{array}{l}\text { 4. How to observe the microstructure of neurons? (Electron } \\
\text { microscope, Immunoelectron microscopy) }\end{array}$ \\
\hline & 5. How to quantify the morphological images? (Stereology) \\
\hline
\end{tabular}

plans and acquired relevant information from a range of resources, including textbooks, libraries and the Internet. Through self-study, discussion, analysis and summary, the group members developed opinions and a scheme for their experiment. The team members collaborated with one another and teachers provided assistance throughout the whole process.

Phase 3: Experimental operations Based on the tasks and research plans developed in Phase 2, the students conducted experiments according to an experimental scheme of their own design using immunohistochemical methods. In the course of the experiment, teachers provided the guidance. The students were graded based on the results of those experiments.

Phase 4: Discussion After the self-learning and experimental operations, team delegates presented their results and held discussions with the other groups. All the students participated in the discussions.

Phase 5: Summary The teachers gave a synopsis of the basic knowledge, basic principles and technical skills covered in the course. Teachers also summarized key and difficult points of the course and addressed common problems encountered by the students. The students participated in the meetings of this phase and provided suggestions about the TBL teaching mode.

\section{LBL group}

The descriptive data of the LBL group appear in Table 1. The 114 students in this group received the same theory by traditional LBL, which was undertaken by the same staff as with the TBL group. After theory learning, the students conducted experimental operations, in which the teachers provided the experimental materials and protocols. Open classroom discussions took place, but the tasks did not constitute the students' research project for their degree.

\section{Evaluation methods}

We used three means of evaluating the study.

\section{Written immunohistochemistry examination} (theoretical test). Students in both the TBL and LBL groups took a final examination after finishing the course. The examination included basic knowledge, basic principles and technical skills related to immunohistochemistry. The scoring staffs were blinded to the identity of the students and their assigned group.

\section{Examination on experimental operations}

(practical test). The results of the experimental operations involving immunohistochemical techniques (Phase 3) were collected and evaluated.

3. Questionnaire survey. After the end of the course, the students completed a questionnaire, which evaluated their satisfaction with the course. Students in both the TBL and LBL groups filled out the questionnaire to rate the course. Satisfaction was evaluated by means of a four-point scale: excellent, good, fair and poor.

\section{Statistical analyses}

We summarized the data from the students' evaluation ratings using descriptive statistics (means, standard deviation [SD], and response rates). We conducted statistical analysis using SPSS 17.0 software for Windows (SPSS Inc., Chicago, IL, USA). Data are presented as means \pm SD. Statistical analysis between the groups was evaluated using $t$ tests and analysis of variance (ANOVA); a $P$ value $<0.05$ was considered significant.

\section{Results}

\section{Participation}

As evident in Table 1, there were no significant differences between the groups in terms of student numbers, sex, age, or specialty $(P>0.05)$. All the students originally included in this study took the final examination in immunohistochemistry. Before and after the course, all the students completed the questionnaire. 


\section{Immunohistochemistry examination results of the two groups}

To determine the extent of the students' knowledge acquisition, we gave a pre-test questionnaire before the course (Details in Additional file 1) and a post-test afterward; we analyzed the differences between the test scores. An analysis of the test scores appears in Fig. 2. We found no difference in the students' pre-test scores. However, the post-test results indicated that the total scores of the TBL group (mean $\pm \mathrm{SD}, 87.3 \pm 9.9$ ) were significantly higher than those of the LBL group $(80.3 \pm 14.3 ; P<0.05$; Figure $2 \mathrm{~A})$. Further analysis of the mean scores of the practical test revealed significant differences: $86.7 \pm 9.1$ in the TBL group versus $73.3 \pm 11.5$ in the LBL group; $P<0.01$. There were no substantial differences between the two groups in the theoretical test $(P>0.05)$. We analyzed the detailed distribution of the scores based on the score for knowledge acquisition. We found that there was no significant difference between the two groups in the theoretical test (Fig. 2b; $P>0.05)$. However, the TBL group achieved the highest scores in the practical test: the number of high scores (>80) in the TBL group was higher than that in the LBL group (Fig. 2c; $P<0.01$ ).

\section{Analysis of questionnaire results}

After the course, the students were asked to complete an anonymous questionnaire. The contents of the questionnaire and the results are shown in Tables 4 and 5 . In all, $84.2 \%$ of the students were positive ("excellent" or "good" on

A

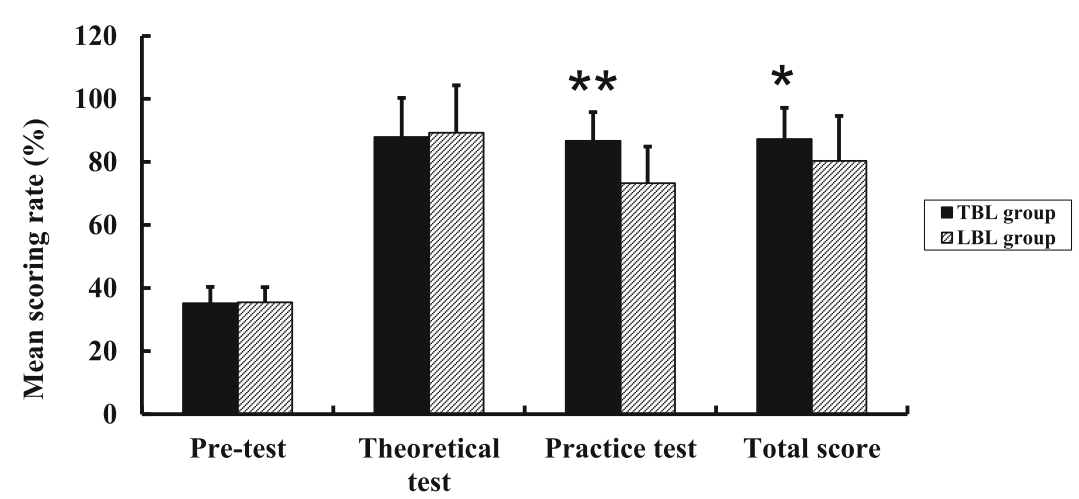

B

\begin{tabular}{|c|c|c|}
\hline Score & $\begin{array}{c}\text { TBL group } \\
\text { Number (\%) }\end{array}$ & $\begin{array}{c}\text { LBL group } \\
\text { Number (\%) }\end{array}$ \\
\hline$>90$ & $10(8.8)$ & $14(12.3)$ \\
\hline $80-89$ & $62(54.4)$ & $59(51.8)$ \\
\hline $70-79$ & $29(25.4)$ & $30(26.3)$ \\
\hline $60-69$ & $13(11.4)$ & $11(9.6)$ \\
\hline$<60$ & $0(0)$ & $0(0)$ \\
\hline
\end{tabular}

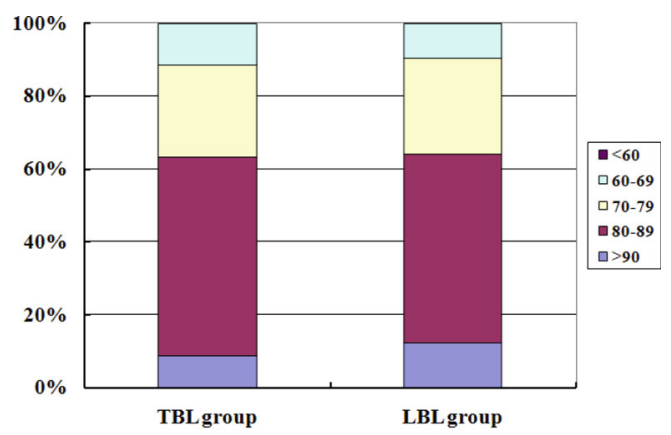

C

\begin{tabular}{|c|c|c|}
\hline Score & $\begin{array}{c}\text { TBL group } \\
\text { Number }(\%)\end{array}$ & $\begin{array}{c}\text { LBL group } \\
\text { Number }(\%)\end{array}$ \\
\hline$>90$ & $13(11.4)$ & $7(6.1)$ \\
\hline $80-89$ & $69(60.5)$ & $57(50.0)$ \\
\hline $70-79$ & $22(19.3)$ & $36(31.6)$ \\
\hline $60-69$ & $10(8.8)$ & $14(12.3)$ \\
\hline$<60$ & $0(0)$ & $0(0)$ \\
\hline
\end{tabular}

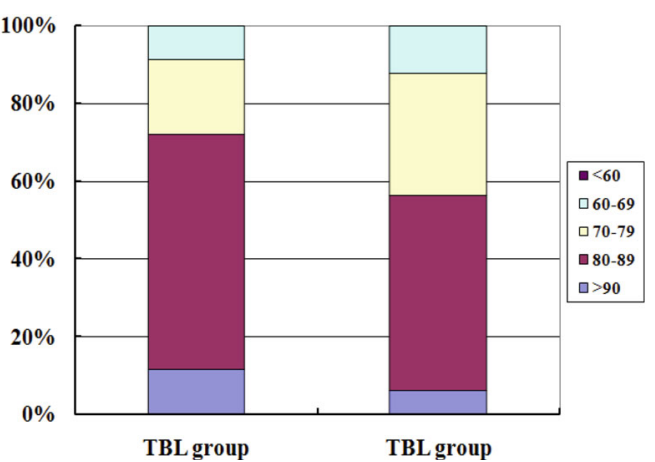

Fig. 2 Results of the final examination. a. Mean examination scores $(X \pm S D)$ of the $\operatorname{TBL}$ group $(n=114)$ and $L B L$ group $(n=114)$. ${ }^{*} P<0.05$, ${ }^{* *} P<0.01$. b. Demographic characteristics for the theoretical test. c. Demographic characteristics for the practical test 
Table 4 Questionnaire results about the teaching mode among students in the TBL and LBL groups

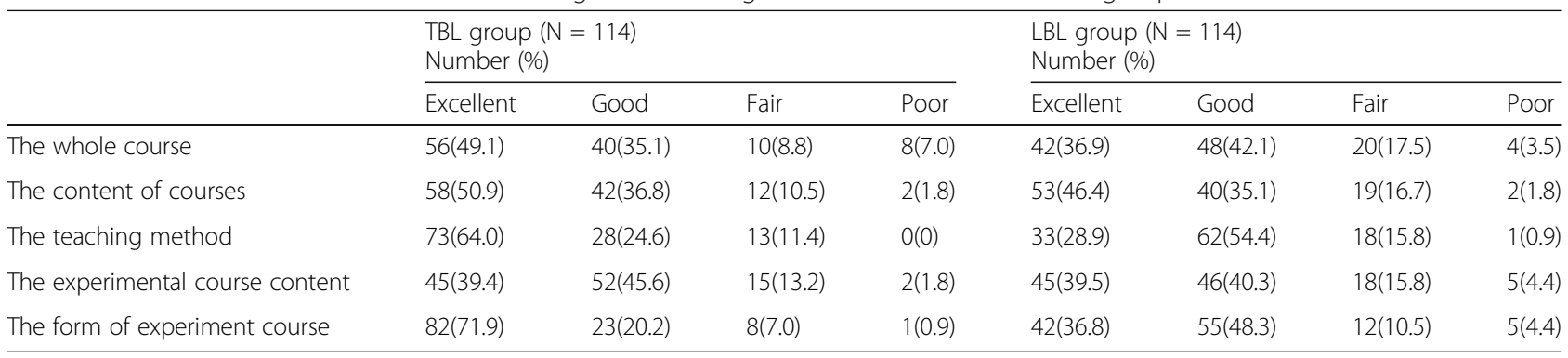

the four-point scale) with respect to course satisfaction for TBL; that figure was $79 \%$ for LBL. Students in the TBL course showed higher satisfaction in terms of curriculum, teaching content, teaching method, experiment content and experiment course than those in the LBL group (Table 4).

In addition to mastering the theory and techniques of immunohistochemistry, an important function of TBL in the present study involved solving problems related to experiments using immunohistochemical techniques. The questionnaire results showed that the TBL model was beneficial in helping the students complete their research projects. The TBL students were able to develop their experimental design skills. They also gained the ability to find relevant documents and acquire immunohistochemical techniques. The TBL model promoted the team members to cooperate in completing their tasks. With respect to the research projects, the LBL students' satisfaction was lower than that of the TBL students (Table 5).

The students regarded TBL as an innovative learning method and agreed that it created an active classroom atmosphere in the immunohistochemistry course (Table 6). Compared with the traditional method, the TBL model enhanced learning motivation and self-learning ability, and learning efficiency; it reinforced problem-solving ability and improved students' ability in cooperation and communication. Thus, the TBL method will probably be welcomed by most students.

\section{Discussion}

Postgraduates possess basic medical knowledge and considerable clinical experience. It is important for postgraduates to improve their problem-solving ability through practical training [17]. TBL can clearly help make a curriculum more relevant to professional practice; as a training approach, TBL can be advocated for enhancing the connections among skills, knowledge and competences [18]. In the present study, the TBL model was used to improve students' problem-solving ability, collaboration, and communication.

As an experimental technology curriculum, the teaching model for immunohistochemistry in many China's universities is still a traditional LBL program. The LBL model can impart knowledge to students systematically and comprehensively, but it is insufficient for solving related problems [10]. In LBL classes, many students have difficulty in linking theory with laboratory exercises. Students blindly follow step-by-step protocols without having proper opportunity to think critically about the task at hand [9]. TBL is a useful method for medical students in that it helps them consider the connections among skills, knowledge, and competences. Our results indicate that the mean theoretical test scores of the TBL group did not significantly differ from those of the LBL group; however, the TBL group achieved the highest scores in the practical test. This finding suggests that our modified TBL imparts knowledge to students and promotes the translation of knowledge into actual practice.

LBL is a good method for imparting basic knowledge to students; however, students' learning initiative is not reinforced owing to the lack of knowledge in solving real problems [10]. The LBL model has the problem of adapting medical education to real challenges; one such

Table 5 Questionnaire results about the students' research projects in the TBL and LBL groups

\begin{tabular}{|c|c|c|c|c|c|c|c|c|}
\hline & \multicolumn{4}{|c|}{$\begin{array}{l}\text { TBL group }(\mathrm{N}=114) \\
\text { Number }(\%)\end{array}$} & \multicolumn{4}{|c|}{$\begin{array}{l}\text { LBL group }(\mathrm{N}=114) \\
\text { Number }(\%)\end{array}$} \\
\hline & Excellent & Good & Fair & Poor & Excellent & Good & Fair & Poor \\
\hline Helpful to complete the project for master degree & $61(53.5)$ & $38(33.3)$ & $14(12.3)$ & $1(0.9)$ & $23(20.2)$ & $43(37.7)$ & $40(35.1)$ & $8(7.0)$ \\
\hline Improve ability of project design & $53(46.5)$ & $45(39.5)$ & $14(12.3)$ & $2(1.7)$ & 15(13.2) & $51(44.7)$ & $40(35.1)$ & $8(7.0)$ \\
\hline Searching related literatures & $63(55.3)$ & $34(29.8)$ & 13(11.4) & $4(3.5)$ & 24(21.1) & $34(29.8)$ & $50(43.9)$ & $6(5.2)$ \\
\hline Mastering related experimental methods & $67(58.8)$ & $37(32.5)$ & $10(8.7)$ & $0(0)$ & 23(20.2) & $57(50.0)$ & $31(27.2)$ & $3(2.6)$ \\
\hline Team members are cooperated to complete tasks. & $32(28.1)$ & $61(53.5)$ & 19(16.7) & $2(1.7)$ & 15(13.2) & $35(30.7)$ & $59(51.7)$ & $5(4.4)$ \\
\hline Teachers play a better role for guiding & $45(39.5)$ & $56(49.1)$ & $12(10.5)$ & $1(0.9)$ & $45(39.5)$ & $37(32.5)$ & $30(26.3)$ & $2(1.7)$ \\
\hline
\end{tabular}


Table 6 Questionnaire results about teaching effects in the TBL and LBL groups

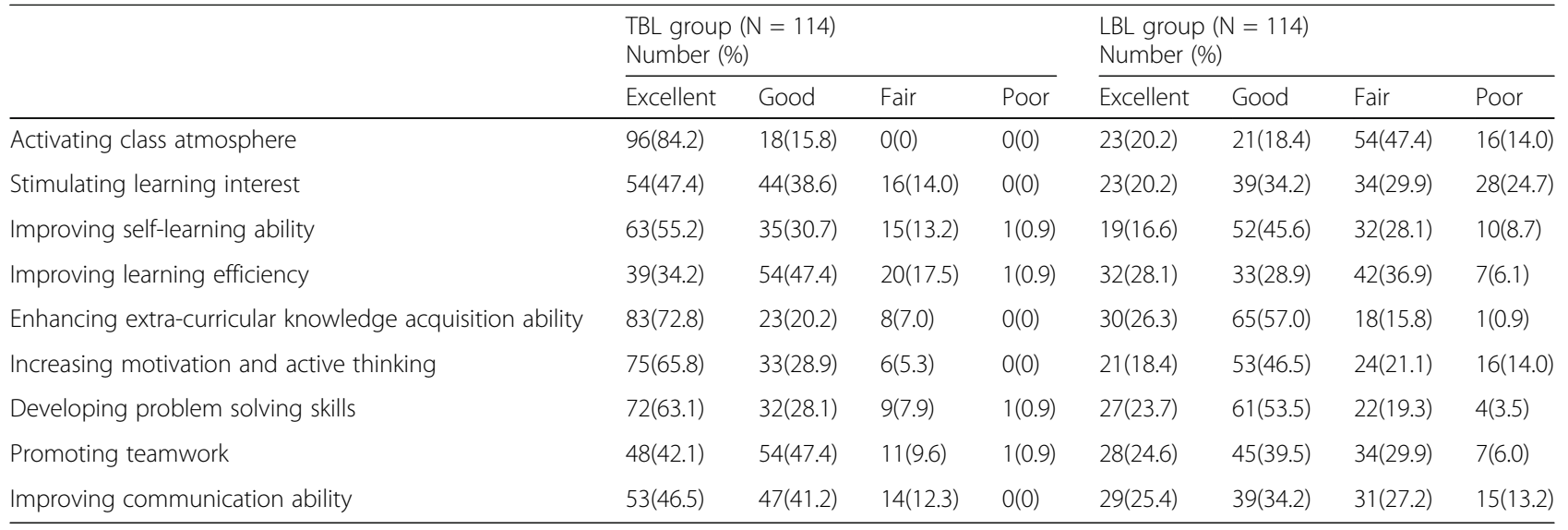

challenge is a disparity between a physician's responsibilities to a patient and research demands. It is necessary for medical education to be designed so as to overcome discipline boundaries $[19,20]$. TBL supports "education for capability." Students' learning is directed toward mastering the competencies relating to the tasks at hand. Publication of research papers is a priority for Chinese postgraduates [21]. Our results show that the TBL model is beneficial for completing research projects. The students found that TBL could improve their project design skills, help them find relevant papers and acquire immunohistochemical techniques. TBL engages students more effectively than LBL in applying knowledge in solving real-world problems.

Innovative interdisciplinary collaborations are needed to train medical workers and researchers [22, 23]. Collaborative approaches to education and training are increasingly expected both among and within institutions. TBL can provide a flexible framework to support collaboration, which motivates students to learn and promotes team collaboration [13]. With TBL in the present study, the students worked collaboratively with one another, developed taskrelated experimental plans and attempted to understand both the tasks themselves and the concepts and mechanisms underlying those tasks. The TBL approach can help break down the barriers that separate different areas of education and training as well as bridge gaps between classmates and teachers.

Communication with patients is an important skill for physicians. Attitudes toward developing communication skills tend to improve as medical students graduate and enter postgraduate training programs [24]. In their postgraduate training, students gradually acquire communication skills in the learning program [25]. The TBL model employed in the present study helped students develop communication skills, including communicating with teachers and classmates.
However, some participants in this study were negative about TBL. Their comments focused mainly on the teaching topics being less structured and less systematically organized than with LBL. Accordingly, it was more difficult for those students to gain a comprehensive understanding of the subject matter. TBL is less effective than LBL among students with poor self-directed study abilities.

In conclusion, our modified TBL imparted basic knowledge to students and also engaged them more effectively in applying knowledge to solve real-world issues; it helped them develop skills related to problem-solving ability, collaboration and communication. Our TBL established a good foundation for the students' futures in both medical research and clinical work.

\section{Conclusions}

Our findings indicate that our modified TBL is a powerful educational strategy and that it is effective for Chinese postgraduate education. Our modified TBL imparted basic knowledge to students and also engaged them more effectively in applying knowledge to solve real-world issues; it helped them develop skills related to problem-solving ability, collaboration, and communication. In conclusion, our TBL established a good foundation for the students' futures in both medical research and clinical work.

\section{Additional file}

Additional file 1: Pre-text questionnaire about immunohistochemistry (DOCX $16 \mathrm{~kb})$

\section{Abbreviations}

LBL: Lecture-based learning; PBL: Problem-based learning; PGME: Postgraduate medical education; TBL: Task-based learning

\section{Acknowledgements}

The authors are deeply grateful for the support of the postgraduate department, Third Military Medical University. We are also grateful to Mr. Yangtao He and Ms. 
Xiyan Wu for their support of this research and the students who took part in our survey without whom we could not have conducted this study.

\section{Funding}

This work was supported by grant 2016A01 (to HL. L) from Educational Reform and Research Key Project of Third Military Medical University, grant yjg123102 (to HL. L) from Postgraduate Education and Teaching Research Reform Project of Chongqing and grant (to YP. T) from Foundation for Young Teacher Training Project of Basic Medicine College, Third Military Medical University.

\section{Availability of data and materials}

No data are shared. If anyone would like to receive our data or materials, we would be very pleased to provide them.

\section{Authors' contributions}

$Y T, X C, F M, J W, Y L, R J$ and $C L, M D$, are associate professors. They teach courses. HW and QC, MD, are Senior Lecturers. They teach experimental courses. LX and HL, MD, Professor, have extensive experience in education and educational research. They have worked for some years and designed the research. $Y T, L X, R J$ and $H L$ conceived and designed the study. $X C, C L$, HW, QC and JW undertook data collection and analysis. YT and HL wrote the first draft of the paper. All authors reviewed drafts of the paper and approved the final manuscript.

\section{Ethics approval and consent to participate}

This study was approved by the Protocol Review Committee of the Undergraduate MD Programme and the Faculty of Health Sciences Research Ethics Board at the Third Military Medical University. We obtained informed consent from all participants before conducting our study. Participants were assured that their involvement in the study would not influence their current or future learning. There was no potential harm to participants.

\section{Consent for publication}

Not applicable.

\section{Competing interests}

The authors declare that they have no competing interests.

\section{Publisher's Note}

Springer Nature remains neutral with regard to jurisdictional claims in published maps and institutional affiliations.

\section{Received: 2 March 2017 Accepted: 30 August 2017}

\section{Published online: 07 September 2017}

\section{References}

1. Bo H, Zhang DH, Zuo TM, Xue DB, Guo JS, Liu MN, Dong JZ, Sun BZ, Zhou J. Survey and analysis of the current state of residency training in medicalschool-affiliated hospitals in China. BMC Med Educ. 2014;14:111.

2. Zhu Y, Zhang CJ, Hu CL. China's postgraduate education practices and its academic impact on publishing: is it proportional? J Zhejiang Univ-SC B. 2014;15(12):1088-92

3. Johansson AC, Durning SJ, Gruppen LD, Olson ME, Schwartzstein RM, Higgins PA. Perspective: medical education research and the institutional review board: reexamining the process. Acad Med. 2011;86(7):809-17.

4. Ton TG, Gladding SP, Zunt JR, John C, Nerurkar VR, Moyer CA, Hobbs N, McCoy M, Kolars JC. The development and implementation of a competency-based curriculum for training in global health research. Am J Trop Med Hyg. 2015;92(1):163-71.

5. Xu D, Sun BZ, Wan XH, Ke Y. Reformation of medical education in China. Lancet. 2010;375(9725):1502-4.

6. Zhang $\mathrm{CJ}$, Zhu Y. China's graduate students need better education in scientific writing and publishing. J Zhejiang Univ-SC B. 2016;17(5):409-12

7. Zheng JW, Zhang SY, Yang C, Guo L, Shen GF, Feng XP, Zhang JZ, Zhang ZY. Current Undergraduate and Postgraduate Dental Education in China. J Dent Educ. 2013;77(1):72-8.

8. Ramos-Vara JA, Miller MA. When tissue antigens and antibodies get along: revisiting the technical aspects of immunohistochemistry-the red, brown, and blue technique. Vet Pathol. 2014;51(1):42-87.
9. Chen J, Zhou J, Sun L, Wu Q, Lu H, Tian J. A new approach for laboratory exercise of pathophysiology in China based on student-centered learning. Adv Physiol Educ. 2015;39(2):116-9.

10. Faisal R. Khalil-ur-Rehman; Bahadur, S.; Shinwari, L., Problem-based learning in comparison with lecture-based learning among medical students. J Pak Med Assoc. 2016;66(6):650-3.

11. Enarson C, Cariaga-Lo L. Influence of curriculum type on student performance in the United States Medical Licensing Examination Step 1 and Step 2 exams: problem-based learning vs. lecture-based curriculum. Med Educ. 2001;35(11):1050-5.

12. Rotthoff T, Ostapczuk MS, de Bruin J, Kroncke KD, Decking U, Schneider M, Ritz-Timme S. Development and evaluation of a questionnaire to measure the perceived implementation of the mission statement of a competency based curriculum. BMC Med Educ. 2012;12:109.

13. Harden R, Crosby J, Davis MH, Howie PW, Struthers AD. Task-based learning: the answer to integration and problem-based learning in the clinical years. Med Educ. 2000;34(5):391-7.

14. Race P. Task-based learning. Med Educ. 2000;34(5):335-6.

15. Vakani F, Jafri W, Ahmad A, Sonawalla A, Sheerani M. Task-based learning versus problem-oriented lecture in neurology continuing medical education. J Coll Physicians Surg Pak. 2014;24(1):23-6.

16. Nazir T. Simple maths of 'task-based learning (TBL)' in Acute Medicine TBL $=$ effective learning + timely completion of tasks + productivity. Med Teach. 2012;34(12):1090.

17. Zhu Y, Zhang CJ, Hu CL. China's postgraduate education practices and its academic impact on publishing: is it proportional? J Zhejiang Univ Sci B. 2014;15(12):1088-92.

18. Koh YH, Wong ML, Lee JJ. Medical students' reflective writing about a taskbased learning experience on public health communication. Med Teach. 2014;36(2):121-9.

19. Fitzgerald JT, Burkhardt JC, Kasten SJ, Mullan PB, Santen SA, Sheets KJ, Tsai A, Vasquez JA, Gruppen LD. Assessment challenges in competency-based education: A case study in health professions education. Med Teach. 2015:1-9.

20. Gruppen LD, Mangrulkar RS, Kolars JC. The promise of competency-based education in the health professions for improving global health. Hum Resour Health. 2012;10:43.

21. Yuan HF, Xu WD, Hu HY. Young Chinese doctors and the pressure of publication. Lancet. 2013;381(9864):E4.

22. Holle LM, Puri S, Clement JM. Physician-pharmacist collaboration for oral chemotherapy monitoring: Insights from an academic genitourinary oncology practice. J Oncol Pharm Pract. 2016;22(3):511-6.

23. Olapade-Olaopa EO, Baird S, Kiguli-Malwadde E, Kolars JC. Growing partnerships: leveraging the power of collaboration through the Medical Education Partnership Initiative. Acad Med. 2014;89(8 Suppl):S19-23.

24. Shankar RP, Dubey AK, Mishra P, Deshpande VY, Chandrasekhar TS, Shivananda PG. Student attitudes towards communication skills training in a medical college in Western Nepal. Educ Health (Abingdon). 2006;19(1):71-84.

25. Gillis AE, Morris MC, Ridgway PF. Communication skills assessment in the final postgraduate years to established practice: a systematic review. Postgrad Med J. 2015:91(1071):13-21.

\section{Submit your next manuscript to BioMed Central and we will help you at every step:}

- We accept pre-submission inquiries

- Our selector tool helps you to find the most relevant journal

- We provide round the clock customer support

- Convenient online submission

- Thorough peer review

- Inclusion in PubMed and all major indexing services

- Maximum visibility for your research

Submit your manuscript at www.biomedcentral.com/submit

\section{Biomed Centra}

